\title{
ANALISIS KEBUTUHAN AIR DOMESTIK DAN NON DOMESTIK DI KABUPATEN GUNUNGKIDUL
}

\author{
Farida Afriani Astuti; Andi Sungkowo; Wisnu Aji Dwi Kristanto \\ Program Studi Teknik Lingkungan, Fakultas Teknologi Mineral, UPN "Veteran" Yogyakarta \\ Jl. SWK 104 Condongcatur Yogyakarta 55285 \\ email: faridaafriani.astuti@gmail.com
}

\begin{abstract}
Water is a key and significant factor in sustaining human life. Variations in the amount of water needed dependant on each region, due to some factors such as the population of all things living and their activities. The north part of Kabupaten Gunungkidul is one example of an area with a lack access to of constant water. The objective of this study is to calculate the water need in the research area of Kabupaten Gunungkidul. The water need calculation is based on domestic and nondomestic demands. Domestic demand consists of the use of water for drinking, bathing, washing, using the toilet, and washing vehicles. It is usually based on the age group, ranging 0-15, $16-65$, and > 65 years old. The non-domestic water is consumed by chicken livestock, goat and cattle farm, and general farming. The data for this study was obtained via a questionnaire as a survey tools. Descriptive statistics methods are used to analyse the data. The varied domestic demand comprised age groups due to their activities.Total daily amounts consumed varied by age group vary from 0, 16-65, and > 65 years old amounting to 32.43 to $91.43,41$ to 113.87, and 38.71 to 105.21 litres per person per day. Non-domestic water needs for livestock, goat farm, and cattle farm were amounted to respectively 0.5, 5, 20 litres per day.
\end{abstract}

Keywords: Domestic Water Needs, Non Domestik Water Needs, Water Resources

\begin{abstract}
Abstrak
Air diperlukan bagi semua makhluk hidup. Besar kecilnya kebutuhan air berbeda disetiap wilayah. Perbedaan kebutuhan air disebabkan oleh banyak faktor, diantaranya adalah faktor jumlah makhluk hidup dan aktivitas yang dilakukan. Kabupaten Gunungkidul bagian utara merupakan salah satu wilayah di Provinsi DIY dengan jumlah sumberdaya air terbatas dan tidak mudah untuk memperolehnya. Tujuan penelitian ini adalah menghitung kebutuhan air di wilayah kajian di Kabupaten Gunungkidul. Kebutuhan air yang dihitung di wilayah kajian meliputi kebutuhan air domestik dan non domestik. Kebutuhan domestik terdiri dari pemakaian air untuk minum, mandi, mencuci, toilet, dan mencuci kendaraan berdasarkan kelompok umur, yaitu umur 0-15, 16 -65, dan > 65 tahun. Sedangkan kebutuhan non domestik merupakan kebutuhan air yang dipergunakan untuk aktivitas peternakan sapi, kambing, dan ayam. Data kebutuhan air diperoleh dengan cara survei dengan alat bantu kuisioner. Analisis kebutuhan air dilakukan dengan metode statistik deskriptif. Kebutuhan air domestik memiliki besaran yang berbeda disetiap kelompok umur akibat perbedaan jenis aktivitas yang dilakukan. Kelompok umur 0-15 tahun memiliki kebutuhan air sebesar 32,43-91,43 liter per orang per hari, kelompok umur 16-65 tahun sebesar 41-113,87 liter per orang per hari, dan kelompok umur > 65 tahun sebesar 38,71-105,21 liter per orang per hari. Kebutuhan air non domestik untuk hewan ternak ayam sebesar 0,5 liter per hari, kambing sebesar 5 liter per hari, dan sapi sebesar 20 liter per hari.
\end{abstract}

Kata Kunci: Kebutuhan Air Domestik, Kebutuhan Air Non Domestik, Sumberdaya Air

\section{PENDAHULUAN}

Air merupakan salah satu kebutuhan primer bagi kehidupan semua makhluk hidup. Tidak ada air maka tidak akan ada kehidupan. Besar kecilnya kebutuhan air berbeda-beda disetiap wilayah. Kebutuhan air 
di definisikan sebagai sejumlah air yang digunakan untuk berbagai peruntukan atau kegiatan masyarakat dalam suatu wilayah, (Admadhani,dkk, 2014). Perbedaan kebutuhan air bagi manusia disebabkan oleh banyak faktor, diantaranya adalah faktor jumlah penduduk dan aktivitas yang dilakukan. Semakin besar jumlah penduduk suatu wilayah maka kebutuhan air akan semakin besar. Begitu juga dengan semakin banyak aktivitas yang dilakukan oleh penduduk maka semakin banyak pula kebutuhan air yang diperlukan. Banyak sedikitnya aktivitas yang dilakukan oleh penduduk dipengaruhi oleh beberapa faktor, salah satunya adalah faktor umur. Semakin banyak penduduk dengan golongan umur produktif biasanya akan semakin banyak aktivitas yang dilakukan sehingga kebutuhan air akan semakin tinggi.

Kabupaten Gunungkidul merupakan salah satu wilayah di Provinsi DIY dengan jumlah sumberdaya air terbatas dan tidak mudah untuk memperolehnya, khususnya Kabupaten Gunungkidul bagian utara. Kondisi tersebut disebabkan karena pada sebagian wilayah cekungan air bawah permukaan di Kabupaten Gunungkidul bagian utara memiliki sistem hidrologi yang spesifik yaitu dengan potensi airtanah yang kecil. Kecilnya potensi air tanah dikarenakan karakteristik batuan yang tidak dapat menyimpan dan meneruskan air dengan baik. Menurut Anonim (2011), pada musim hujan umumnya kedalaman airtanah pada wilayah tersebut lebih dari 15 m dengan fluktuasi kedalaman muka airtanah berkisar antara 4-15 meter. Pada musim kemarau sebagian besar airtanah dijumpai pada lapisan akuifer yang dalam (> 40 meter) dan ada yang berupa alur-alur sungai bawah tanah yang sulit untuk di deteksi sehingga hal ini menyulitkan masyarakat pada wilayah tersebut untuk memanfaatkan air dalam memenuhi kebutuhan air.

Beberapa wilayah di Kabupaten Gunungkidul menurut Anonim (2018) yang memiliki keterbatasan jumlah sumberdaya air, antara lain: Desa Mertelu, Desa Tegalrejo, Desa Ngoro-Oro, Desa Serut, Desa Kampung, Desa Jurangjero, Desa Tancep, Desa Karangsari, Desa Pundungsari, dan Desa Semin. Didasari oleh pentingnya pemenuhan kebutuhan air dalam kondisi geofisik lingkungan yang kurang mendukung, maka tujuan dari penelitian ini adalah menghitung kebutuhan air di wilayah kajian yang dapat digunakan sebagai dasar kebijakan pemenuhan sarana penunjang kebutuhan air dibeberapa wilayah di Kabupaten Gunungkidul. 


\section{METODOLOGI PENELITIAN}

Kebutuhan air di Kabupaten Gunungkidul dihitung untuk kondisi saat ini (eksisting) yang meliputi kebutuhan air domestik dan non domestik (peternakan). Kebutuhan domestik terdiri dari pemakaian air untuk minum, mandi, mencuci, toilet, dan mencuci kendaraan. Kebutuhan air domestik dihitung berdasarkan jumlah penduduk dan konsumsi/pemakaian air per kapita per hari. Data konsumsi/pemakaian air per kapita per hari dari setiap aktivitas domestik diperoleh dari hasil interview menggunakan kuisioner yang didalamnya terdapat beberapa pertanyaan mengenai jumlah pemakaian air dalam satuan liter. Adapun jumlah responden yang diinterview untuk mendapatkan data konsumsi/pemakaian air dihitung menggunakan rumus Slovin dengan error margin sebesar 20\%.

Persamaan Slovin:

$$
n=\frac{\mathrm{N}}{1+\mathrm{N} \mathrm{e}^{2}}
$$

Keterangan:

n : Jumlah sampel

$\mathrm{N} \quad$ : Populasi

e : error margin

Jumlah populasi penduduk dibedakan berdasarkan golongan umur menjadi tiga kelompok, yaitu kelompok 0-15 tahun, kelompok 16-65 tahun, dan kelompok lebih dari (>) 65 tahun. Analisis kebutuhan air dilakukan dengan metode statistik deskriptif yang diartikan sebagai bagian dari statistika yang membahas cara pengumpulan dan penyajian data, sehingga mudah untuk dipahami dan memberikan informasi yang berguna (Susetyo, 2017).

Wilayah kajian terdiri dari 10 desa dimana setiap desa diambil sampel dusun untuk menentukan responden yang akan disurvei kebutuhan airnya, baik kebutuhan air domestik maupun non domestik. Sampel dusun yang diambil yaitu Dusun Mertelu, Guyangan Kidul, Guyangan Lor, dan Soka untuk Desa Mertelu. Dusun Cremo, Gupit, dan Ngipik untuk Desa Tegalrejo. Dusun Soka, Salaran, Gunungasem, Sepat, Tawang, dan Gembyong untuk Desa Ngoro-Oro. Dusun Dawung untuk Desa Serut. Dusun Pagerjurang dan Gununggambar untuk Desa Kampung. Dusun Jurangjero, Kaliwuluh, Wonosari, dan gambarsari untuk Desa Jurangjero. Dusun Bundelan dan Sendangrejo untuk Desa Tancep. Dusun Karang, Nganjir, dan Jetak untuk Desa Karangsari. Dusun Dondong untuk Desa Pundungsari dan Dusun Pucungmalang untuk Desa Semin. Pengambilan sampel dusun didasari oleh 
professional adjustment menggunakan analisis spasial dari Peta Daerah Sulit Air di Kabupaten Gunungkidul (Anonim, 2018).

\section{HASIL DAN PEMBAHASAN}

\subsection{Kebutuhan Air Domestik}

Kebutuhan air domestik diartikan sebagai kebutuhan air yang digunakan untuk keperluan rumah tangga. Kebutuhan air dibedakan berdasarkan golongan umur untuk mengetahui jenis aktivitas yang dilakukan pada masing-masing kelompok umur yang mempengaruhi banyak sedikitnya kebutuhan air. Karena pada dasarnya kebutuhan air semakin meningkat seiring dengan peningkatan usia (Briawan, dkk.,2011). Dengan demikian diasumsikan bahwa semakin meningkat usia maka semakin banyak pula aktivitas yang dilakukan sehingga kebutuhan air akan semakin banyak. Banyaknya kebutuhan air di wilayah kajian dapat dilihat pada Tabel 1.

Tabel 1 menunjukkan bahwa konsumsi pemakaian air per kapita di setiap Dusun memiliki karakteristik yang berbeda-beda. Dari 27 Dusun yang ada di wilayah kajian terdapat 11 Dusun dengan kebutuhan air terbesar berada pada golongan umur 0 - 15 tahun (Dusun Guyangan Lor, Cremo, Gupit, Serut, dan Pucungmalang) dan golongan umur > 65 tahun (Dusun Soka, Ngipik, Gununggambar, Bundelan, dan Wonosari). Besarnya kebutuhan air pada golongan umur 0 -15 tahun dipengaruhi oleh banyaknya aktivitas untuk membersihkan diri (minum, mandi dan toilet) yang dilakukan, sedangkan untuk golongan umur > 65 tahun banyaknya kebutuhan air karena dipengaruhi oleh beragamnya aktivitas rumah tangga yang dilakukan (minum, mandi, mencuci, dan toilet).

Hasil survei kebutuhan air pada Tabel 1 juga menunjukkan terdapat beberapa dusun dengan kebutuhan air tertinggi terdapat pada golongan umur 16 - 65 tahun yaitu Dusun Guyangan Kidul dan Dusun Tawang. Banyaknya kebutuhan air pada kelompok umur 16 - 65 tahun dipengaruhi oleh penambahan aktivitas mencuci kendaraan dan memasak yang membutuhkan banyak air. Dusun Guyangan Kidul Desa Mertelu memiliki jumlah penduduk 345 jiwa dengan komposisi penduduk terbesar adalah umur produktif (16-65 tahun) sebanyak 233 jiwa (67,57\%) dengan kebutuhan air per kapita 45,50 liter/hari atau 10.601,5 liter/hari untuk satu dusun. Sedangkan komposisi penduduk terkecil adalah golongan umur 0-15 tahun sebanyak 49 jiwa (14,2\%) dengan kebutuhan air per kapita 38 liter/hari atau 1.892,22 liter/hari untuk satu dusun. 
Pola yang sama juga terlihat untuk Dusun Tawang di Desa Ngoro-Oro, konsumsi pemakaian air paling besar adalah pada golongan umur produktif (16-65 tahun) sebesar 112,49 liter/hari/orang. Akan tetapi konsumsi air paling kecil terdapat pada golongan umur 0-15 tahun yaitu sebesar 75,71 liter/hari/orang meskipun jumlah penduduk umur tersebut bukan merupakan jumlah terendah di Dusun Tawang. Dengan demikian, dari pola kebutuhan air tersebut semakin memperjelas bahwa kebutuhan air di suatu wilayah tidak hanya dipengaruhi oleh jumlah penduduk saja melainkan juga dipengaruhi oleh jenis aktivitas individu yang tercermin dari masing-masing kelompok umur.

Tabel 1. Rekapitulasi Kebutuhan Air Domestik di Kabupaten Gunungkidul

\begin{tabular}{|c|c|c|c|c|c|c|c|c|c|c|c|c|}
\hline \multirow{3}{*}{ No } & \multirow{3}{*}{ Desa } & \multirow{3}{*}{ Dusun } & \multicolumn{3}{|c|}{ Jumlah warga } & \multirow{3}{*}{$\begin{array}{c}\text { Total } \\
\text { warga }\end{array}$} & \multicolumn{6}{|c|}{ Kebutuhan air (liter) } \\
\hline & & & \multirow{2}{*}{ A } & \multirow{2}{*}{ B } & \multirow{2}{*}{ C } & & \multicolumn{3}{|c|}{ Rata-rata per orang } & \multicolumn{3}{|c|}{ Satu dusun } \\
\hline & & & & & & & $\mathbf{A}$ & $\mathbf{B}$ & C & A & B & C \\
\hline 1 & Mertelu & Mertelu & 309 & 93 & 30 & 432 & 32,49 & 62,67 & 48 & 10039 & 5828 & 1440 \\
\hline 2 & Mertelu & $\begin{array}{l}\text { Guyangan } \\
\text { kidul }\end{array}$ & 49 & 233 & 63 & 345 & 38,62 & 45,50 & 42,20 & 1892,22 & 10601,5 & 2658,60 \\
\hline 3 & Mertelu & Guyangan lor & 106 & 256 & 131 & 493 & 47,75 & 44 & 40 & 5061,50 & 11264 & 5240 \\
\hline 4 & Mertelu & Soka & 79 & 203 & 47 & 329 & 34,67 & 56,67 & 59,60 & 2738,67 & 11503.33 & 2801,20 \\
\hline 5 & Tegalrejo & Cremo & 233 & 471 & 57 & 761 & 47,93 & 41,63 & 38,71 & 11167,4 & 19605.38 & 2206,71 \\
\hline 6 & Tegalrejo & Gupit & 61 & 270 & 71 & 402 & 58,10 & 41,00 & 47 & 3544,10 & 11070 & 3337 \\
\hline 7 & Tegalrejo & Ngipik & 32 & 88 & 26 & 146 & 32,43 & 46,50 & 46,67 & 1037,71 & 4092 & 1213,33 \\
\hline 8 & Ngoro-oro & Soka & 116 & 441 & 155 & 712 & 56,57 & 74,22 & 65,5 & 6562,12 & 32731 & 10152,5 \\
\hline 9 & Ngoro-oro & Salaran & 107 & 327 & 32 & 466 & 75,31 & 111,12 & 76,12 & 8058,44 & 36335,9 & 2435,81 \\
\hline 10 & Ngoro-oro & Gunungasem & 77 & 327 & 96 & 500 & 91,43 & 105,21 & 111 & 7040,11 & 34403,7 & 10656 \\
\hline 11 & Ngoro-oro & Sepat & 64 & 199 & 44 & 307 & 78,14 & 113,87 & 80,81 & 5001,14 & 22659,1 & 3555,62 \\
\hline 12 & Ngoro-oro & Tawang & 54 & 163 & 40 & 257 & 75,71 & 112,49 & 105,21 & 4088,57 & 18335,6 & 4208,42 \\
\hline 13 & Ngoro-oro & Gembyong & 67 & 132 & 71 & 270 & 63 & 59,38 & 49,8 & 4221 & 7838,16 & 3535,8 \\
\hline 14 & Serut & Dawung & 106 & 292 & 132 & 530 & 63,5 & 61 & 58,29 & 6731 & 17812 & 7694,28 \\
\hline 15 & Kampung & Pagerjurang & 101 & 264 & 97 & 462 & 64,2 & 85,41 & 76,48 & 6487,08 & 22548,7 & 7419,16 \\
\hline 16 & Kampung & Gununggambar & 51 & 163 & 36 & 250 & 65,2 & 70,2 & 79,78 & 3325,92 & 11443,7 & 2872,28 \\
\hline 17 & Jurangjero & Jurangjero & 89 & 230 & 72 & 391 & 59,55 & 81,73 & 56,68 & 5299,95 & 18798 & 4081,44 \\
\hline 18 & Tancep & Bundelan & 155 & 431 & 153 & 739 & 59,64 & 70,18 & 73,89 & 9244,64 & 30251,5 & 11306,1 \\
\hline 19 & Tancep & Sendangrejo & 197 & 509 & 126 & 832 & 77,75 & 82,9 & 75,36 & 15316,7 & 42232,1 & 9495,5 \\
\hline 20 & Jurangjero & Kaliwuluh & 207 & 496 & 172 & 875 & 85,31 & 98,82 & 95,55 & 17659,6 & 49017,4 & 16435,2 \\
\hline 21 & Jurangjero & Wonosari & 117 & 237 & 78 & 432 & 77 & 82,61 & 90,98 & 9009 & 19578,8 & 7096,76 \\
\hline 22 & Jurangjero & Gambarsari & 64 & 114 & 22 & 200 & 82,4 & 82,40 & 81,06 & 5273,6 & 9394,11 & 1783,42 \\
\hline 23 & Karangsari & Karang & 131 & 256 & 63 & 450 & 38,3 & 65,5 & 38,8 & 5017,3 & 16768 & 2444,4 \\
\hline 24 & Karangsari & Nganjir & 111 & 479 & 98 & 688 & 54,67 & 97,11 & 96,83 & 6068,37 & 46515,6 & 9489,34 \\
\hline 25 & Karangsari & Jetak & 115 & 440 & 75 & 630 & 39 & 63 & 47 & 4329 & 30177 & 4606 \\
\hline 26 & Pundungsari & Dondong & 41 & 97 & 28 & 166 & 53,4 & 92,7 & 77,83 & 6141 & 40794,1 & 5837,47 \\
\hline 27 & Semin & Pucungmalang & 123 & 301 & 111 & 535 & 67,5 & 59,8 & 56,33 & 2767,5 & 5807,87 & 1577,24 \\
\hline
\end{tabular}

Keterangan: A (umur 0-15 tahun), B (umur 16-65 tahun), dan C (umur $>65$ tahun)

\subsection{Kebutuhan Air Non Domestik}

Kebutuhan air non domestik di wilayah kajian dilihat dari kebutuhan air untuk peternakan sapi, kambing, dan ayam. Kebutuhan air untuk pertanian tidak dihitung dikarenakan sumber air untuk 
kegiatan pertanian di wilayah kajian banyak menggantungkan dari air hujan. Dari 27 Dusun di wilayah kajian memiliki jumlah hewan ternak sebanyak 2.496 ekor sapi, 2.802 ekor kambing, dan 10.147 ekor ayam. Hasil survei kebutuhan air non domestik menunjukkan hasil yang hampir sama disetiap jenis hewan ternak. Ayam membutuhkan air sebesar 0,5 liter per hari, kambing membutuhkan air sebesar 5 liter per hari, dan sapi membutuhkan air sebesar 20 liter per hari. Adapun data rekapitulasi kebutuhan air non domestik di wilayah kajian dapat dilihat pada Tabel 2.

Tabel 2. Rekapitulasi Kebutuhan Air Non Domestik di Kabupaten Gunungkidul

\begin{tabular}{|c|c|c|c|c|c|c|c|c|c|c|c|}
\hline \multirow{3}{*}{ No } & \multirow{3}{*}{ Desa } & \multirow{3}{*}{ Dusun } & \multicolumn{3}{|c|}{ Hewan Ternak } & \multicolumn{6}{|c|}{ Kebutuhan Air Hewan Ternak (liter) } \\
\hline & & & \multirow{2}{*}{ A } & \multirow{2}{*}{ B } & \multirow{2}{*}{$\mathbf{C}$} & \multicolumn{3}{|c|}{ Rata-rata per ekor } & \multicolumn{3}{|c|}{ Satu dusun } \\
\hline & & & & & & $\mathbf{A}$ & $\mathbf{B}$ & $\mathbf{C}$ & $\mathbf{A}$ & B & $\mathbf{C}$ \\
\hline 1 & Mertelu & Mertelu & 18 & 30 & 183 & 20 & 2 & 0,25 & 360 & 60 & 45,75 \\
\hline 2 & Mertelu & Guyangan kidul & 24 & 41 & 246 & 20 & 1.5 & 0,31 & 480 & 61,5 & 76,26 \\
\hline 3 & Mertelu & Guyangan lor & 23 & 39 & 237 & 20 & 2.2 & 0,18 & 460 & 89,11 & 42,66 \\
\hline 4 & Mertelu & Soka & 27 & 45 & 273 & 20 & 2 & 0,5 & 540 & 90 & 136,5 \\
\hline 5 & Tegalrejo & Cremo & 38 & 64 & 384 & 20 & 2 & 0,5 & 760 & 128 & 192 \\
\hline 6 & Tegalrejo & Gupit & 25 & 44 & 255 & 20 & 2 & 1 & 500 & 88 & 255 \\
\hline 7 & Tegalrejo & Ngipik & 35 & 59 & 357 & 20 & 2 & 1 & 700 & 118 & 357 \\
\hline 8 & Ngoro-oro & Soka & 185 & 170 & 500 & 17.5 & 5 & 0,5 & 3238 & 850 & 250 \\
\hline 9 & Ngoro-oro & Salaran & 157 & 63 & 229 & 20 & 5 & 0,5 & 3140 & 315 & 114,5 \\
\hline 10 & Ngoro-oro & Gunungasem & 200 & 96 & 420 & 20 & 7.5 & 0,5 & 4000 & 720 & 210 \\
\hline 11 & Ngoro-oro & Sepat & 110 & 35 & 250 & 17.5 & 5 & 0,5 & 1925 & 175 & 125 \\
\hline 12 & Ngoro-oro & Tawang & 70 & 17 & 345 & 17.5 & 5 & 0,5 & 1225 & 85 & 172,5 \\
\hline 13 & Ngoro-oro & Gembyong & 60 & 50 & 325 & 22.5 & 5 & 0,5 & 1350 & 250 & 162,5 \\
\hline 14 & Serut & Dawung & 205 & 112 & 465 & 20 & 5 & 0,5 & 4100 & 560 & 232,5 \\
\hline 15 & Kampung & Pagerjurang & 120 & 200 & 500 & 20 & 5 & 0,5 & 2400 & 1000 & 250 \\
\hline 16 & Kampung & Gununggambar & 50 & 150 & 220 & 20 & 5 & 0,5 & 1000 & 750 & 110 \\
\hline 17 & Jurangjero & Jurangjero & 100 & 95 & 500 & 20 & 5 & 0,5 & 2000 & 475 & 250 \\
\hline 18 & Tancep & Bundelan & 23 & 50 & 325 & 20 & 5 & 0,5 & 460 & 250 & 162,5 \\
\hline 19 & Tancep & Sendangrejo & 30 & 50 & 180 & 20 & 5 & 0,5 & 600 & 250 & 90 \\
\hline 20 & Jurangjero & Kaliwuluh & 230 & 400 & 287 & 20 & 5 & 0,5 & 4600 & 2000 & 143,5 \\
\hline 21 & Jurangjero & Wonosari & 160 & 60 & 400 & 20 & 5 & 0,5 & 3200 & 300 & 200 \\
\hline 22 & Jurangjero & Gambarsari & 100 & 50 & 320 & 20 & 5 & 0,5 & 2000 & 250 & 160 \\
\hline 23 & Karangsari & Karang & 88 & 167 & 698 & 20 & 5 & 0,5 & 1760 & 835 & 349 \\
\hline 24 & Karangsari & Nganjir & 135 & 208 & 615 & 16 & 3.25 & 0,75 & 2160 & 676 & 461,25 \\
\hline 25 & Karangsari & Jetak & 60 & 98 & 498 & 16 & 5 & 0,75 & 960 & 490 & 373,5 \\
\hline 26 & Pundungsari & Dondong & 25 & 44 & 297 & 13 & 5 & 0,73 & 325 & 220 & 216,81 \\
\hline 27 & Semin & Pucungmalang & 198 & 365 & 838 & 20 & 4.5 & 1,4 & 3960 & 1642,5 & 1173,2 \\
\hline
\end{tabular}


Kebutuhan air non domestik di wilayah kajian untuk jenis ternak sapi memiliki hasil yang lebih kecil jika dibandingkan dengan tabel unit kebutuhan air untuk peternakan yang di tetapkan oleh SNI 196728.1-2002 yang terdapat pada Tabel 3. Akan tetapi untuk jenis ternak kambing dan ayam memiliki hasil yang sama. Pada Tabel 3 menunjukkan bahwa kebutuhan air untuk sapi sebesar 40 liter sedangkan pada hasil survei hanya sebesar 20 liter. Perbedaan konsumsi air pada jenis ternak sapi menunjukkan bahwa telah terjadi adaptasi fisiologis pada ternak sapi. Adaptasi fisiologis merupakan perilaku penyesuaian makhluk hidup terhadap lingkungan melalui fungsi kerja organ tubuh untuk bertahan hidup. Sapi beradaptasi dengan lingkungan di wilayah kajian yang memiliki keterbatasan jumlah air.

Tabel 3. Unit Kebutuhan Air Untuk Peternakan

\begin{tabular}{ll}
\hline \multicolumn{1}{c}{ Jenis Ternak } & Konsumsi Air \\
\hline 1. Sapi/Kerbau & 40 \\
2. Domba/Kambing & 5 \\
3. Babi & 6 \\
4. Unggus & 0,6 \\
\hline Sumber: Kompendium Pertanian (1981) llocob.V.Netherland dalam SNI 19-6728.1-2002
\end{tabular}

Persentase penggunaan air non domestik dibandingkan dengan total konsumsi air di wilayah kajian adalah sebesar 7,14\%. Hasil tersebut terbilang kecil karena perhitungan air non domestik di wilayah kajian tidak termasuk kebutuhan air untuk pertanian melainkan hanya untuk kebutuhan air peternakan sapi, kambing, dan ayam saja.

\section{KESIMPULAN}

Kebutuhan air domestik diwilayah kajian memiliki besaran yang berbeda disetiap kelompok umur. Kelompok umur 0 - 15 tahun memiliki kebutuhan air per kapita sebesar 32,43 - 91,43 liter per hari. Kelompok umur 16 - 65 tahun memiliki kebutuhan air per kapita sebesar 41 - 113,87 liter per hari. Kelompok umur > 65 tahun memiliki kebutuhan air per kapita sebesar 38,71 - 105,21 liter per hari. Perbedaan kebutuhan air domestik disetiap kelompok umur dipengaruhi oleh jenis aktivitas yang sering dilakukan. Kebutuhan air non domestik di wilayah kajian menunjukkan hasil yang hampir sama disetiap jenis hewan ternak. Ayam membutuhkan air sebesar 0,5 liter per hari, kambing membutuhkan air sebesar 5 liter per hari, dan sapi membutuhkan air sebesar 20 liter per hari. 


\section{DAFTAR PUSTAKA}

Anonim. (2011), Pemetaan Zonasi Konservasi Air Tanah di Cekungan Air Tanah Gunungkidul. Dinas Pekerjaan Umum Perumahan dan Energi Sumberdaya Mineral Provinsi Daerah Istimewa Yogyakarta.

Anonim, (2018), Identifikasi Daerah Sulit Air di Kabupaten Gunungkidul. Dinas Pekerjaan Umum Perumahan dan Energi Sumberdaya Mineral Provinsi Daerah Istimewa Yogyakarta.

Admadhani, Novita, D., Haji, Sutan, A. T., Susanawati, Dewi. L., (2014), Analisis Ketersediaan Dan Kebutuhan Air Untuk Daya Dukung Lingkungan (Studi Kasus Kota Malang), Jurnal Sumberdaya Alam dan Lingkungan, 3(1), pp.13-20.

Briawan, Dodik., Tyas, Sedayu, R., Ekayanti, I., (2011), Kebiasaan Minum dan Asupan Cairan Remaja di Perkotaan, Jurnal Gizi Klinik Indonesia,1 (8), pp. 36-41.

Susetyo, B., (2017) Statistika untuk Analisis Data Penelitian. PT. Refika Aditama. Bandung. SNI 19-6728.1-2002, Penyusunan Neraca Sumberdaya Bagian 1: Sumber Daya Air Spasial. 